\title{
Information System Development for The Service Improvement and Its Effectiveness at PUSBIS UINSA
}

\author{
Aslihatul Millah ${ }^{1, *}$, M. Abdul Aziz ${ }^{2}$, Tsania Saraswati ${ }^{3}$, Pipit Merit Biyanti ${ }^{4}$, Taufik Siraj ${ }^{5}$ \\ 1, 2, 3,4 Information SystemDepartment, Faculty of Science and Technology; ${ }^{5}$ Arabic Education Department, Faculty of Tarbiyah and Education, \\ UIN SunanAmpel Surabaya, \\ J1. A. Yani 117 Surabaya, Indonesia, 602111. Tel. +62-31-213214235, Fax. +62-31-8410298. \\ Email*: aslihaalmillah@gmail.com
}

\begin{abstract}
Many companies or agencies are aware of the role of information technology as a supporter to achieve their vision, mission, and goals nowadays. In 2013, IAIN Sunan Ampel Surabaya changed its name to UINSA and its financial management system is regulated in BLU. This indicates that UINSA must become a self-supporting college financially and increase its income. Reviewing these phenomena, this research would like to develop an information system/application management information system for the PUSBIS of UINSA which focusing on PUSBIS center, Greensa.in, and public facility. The purpose of this study is to know how to develop the information system and its effectiveness in improving service usage of assets / public facilities in UINSA. For that, this research uses the R\&D method. The R \& D used in this research is R \& D level 4 due to this paper will research and develop new products. The results of this study are the settled information system and its statements that information systems that have been built to improve services in lending/usage of assets in PUSBIS.
\end{abstract}

Keywords: Assets, Information System, Agile, R\&D.

Abbreviations: Islamic State University of SunanAmpel Surabaya (UINSA), Public Services Agency (BLU), Business Development Unit (PUSBIS), Information System (IS), Research and Development Method (RnD/R\&D), Information Technology (IT).

\section{INTRODUCTION}

Many companies or agencies are aware of the role of information technology as a supporter to achieve their vision, mission, and goals nowadays. In 2013, IAIN Sunan Ampel Surabaya changed its name to UINSA and its financial management system is regulated in BLU. This indicates that UINSA must become a selfsupporting college financially and increase its income.Based on the historical review, there was a written mission from the PUSBIS of UINSA and the transformation of IAIN to UINSA higher education institutions issued an indication to increase and manage independent income and this is stated in the statute (legal status) (KEMENAG, 2015) of BLU.

PUSBIS has many business area such as asset rent, printing, market, fitness center and so on. PUSBIS has business assets in different places such as Greensa Inn also. Greensa Inn is in a strategic location and has tremendous selling potential and in business operations that support its vision, mission and goals (PUSBIS, 2015). Some of PUSBIS assets located at the different venue with the main location of UINSA.Unfortunately, until now all business process activities at PUBIS including lending and leasing assets have been done manually. All pieces of information are recorded in a book. This often occurs toward miss information and data gaps. This study tries to provide a solution in the form of migration from a manual to a computational based process with IS preparation. Then, the researchers tried to do a preliminary study of how the effectiveness of IS in improving services at PUSBIS.

\section{MATERIALS AND METHODS}

\section{Study Area \\ Information System (IS)}

The information system insists on two words, information and system. Raymon Mcleod in 2001 thought almost the same as Gordon B Davis in 1984 that the system is a collection of elements or parts that are interconnected with each other with integrated and have the same operation to achieve a goal or goal. So the system is a close unit that interacts with each other's operations.

While information is a very crucial value for a company or organization. The information itself is the result of data that has been processed. Data here is something that represents reality. Information in a company is very meaningful as control or parameter to take a policy and manage its resources (Raschania, 2011). So the information system is a linkage to process data into information. With this understanding, it is a very understandable understanding that the information system has a component to produce a piece of 
information. It can look below about the IS components are (Leod, 20014) hardware such as computers, servers, and CD Rom, then software like a programming language editor and the last is human device / brainware like the network programmer/network and so forth.

\section{Conditions for Using IS at UINSA}

Based on the observation, UINSA which at that time was still called IAIN Surabaya has started to use the IS for academic information systems (SIAKAD) since 2010. In this circumstance, the university buys to a vendor in Surabaya. Then after changing its name to UIN Sunan Ampel Surabaya and have started sufficient human resources for establishing and maintaining the IS.

\section{Related Research}

"Segmenting critical factors for enhancing the use of IT in humanitarian supply chain management", a paper from the science direct website states that the increased use of information technology in supply chain management in a company in India. Information technology there has even become a strategic plan for the development and future of the company. This paper states that information technology is like top-level management because it was very meaningful in decision making (Rameshb, 2015).

The use of electronic government in Indonesia is still recent and there are many obstacles and challenges for implementing the electronic government. However, the electronic government has certainly achieved clean and good governance even though clean and good governance does not always take the form of electronic government. This finding is in the journal that belongs to Sari and Winarno 2012 (Dewi, 2012).

Ricky Akbar, et al in their work said that this Jibas application had fulfilled expectations and issued outputs that were in line with the needs of the academic system. Jibas application is an application to manage data and needs in educational institutions. Jibas application is used in the academic system at the school to solve academic data management problems because it has not been integrated with each other so it takes a very long time to just recapitulate all academic data (Ricky, 2015). There are several variations suchasoffersservices, programs, messages, and media that can be done by a company when something created is known by the customer (Yuliar, 2001).

The Boston Consulting Group is a global management consulting company said in its annual research that the use of information technology in business can do the following (The Boston Consulting Group, NY): Investment optimization, set the schedule for the company's HR agenda, IT is an indicator of business up and down.

\section{Procedures}

This chapter would like to present about the research methodology that guide the start till the end of this research completion.In a sense of this methodology is adapted from R\&D methodology. This methodology will discuss in detail on the next chapter. The methodology will show at the flowchart below:

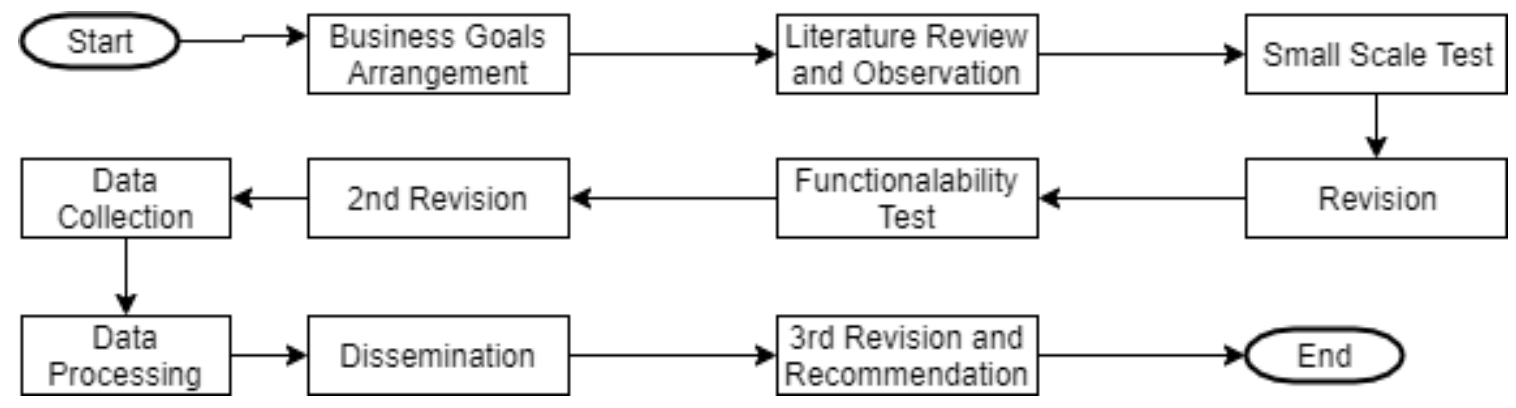

Figure 1. Research Methodology.

Estimating from the research function, this research uses R\&D methods. The principle of the selection of research methods due to this method is more fitting for the characteristics of this study which serves to assist the implementation of work (Sugiyono, 2016). In this study, using the 4th level of R\&D method because of the following considerations: reporting and bookkeeping transactions at the PUSBIS UINSA are still not online. At PUSBIS UINSA, the recording of the use of physical assets is still manual using excel.in this case, researchers still refer to the IS development framework. However, this time adopted the nature of agile because agile is the nature of the development of information systems that are fast, responsive. This was done because of the following considerations:1. Limited time and funding of researchers 2 . Response to changes in demand in the middle 


\section{RESULTS AND DISCUSSION}

\section{Business Goals Arrangement}

All development and implementation of IS and IT must be in accordance with business objectives. As much as possible IT is not only support but also a strategic asset. This foundation was launched from the objective framework of information technology control, namely the COBIT framework (ITGI, 2007). It can be seen in the main big picture that the business objectives mentioned above must be known before any process is carried out. In this study, the development of IS has to support the vision and mission of UINSA and one of the missions of the PUSBIS that reads "Managing trustful and productive campus assets" (PUSBIS, 2015).

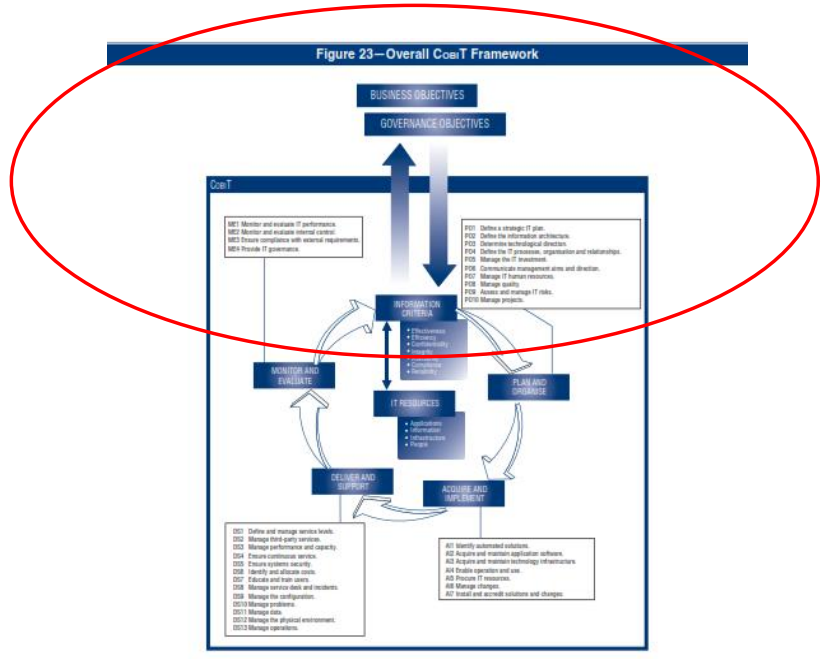

Figure 2. Overall COBIT Framework

\section{Literature Review and Observation}

The literature study conducted is to study the basics of the law and the auspices of PUSBIS UINSA such as journal related to the use of IT and IS, UINSA BLU and UINSA legal statute, references that are relevant to the research problem, company profile of PUSBIS UINSA, UINSA and PUSBIS Strategic Planning (RENSTRA). Data collection on this research with the questionnaire using sampling. In research all elements of the population have the opportunity to be sampled, so the sampling category is probability sampling. Then the observation was conducted to go directly to the related unit and PUSBIS as well to ensure the resources that will operate the product to be developed. To facilitate the work of researchers in this case researchers map with the RACI (Responsibility, Accountability, Consulted, Informed) model tools (Susanto, 2017). The RACI model is a tool that helps define the main tasks and functions (TUPOKSI), so it can help clarify who does what. The RACI model consists of the following:
Table 1. RACI Chart.

\begin{tabular}{|c|c|c|c|c|}
\hline Activities & PUSBIS & $\begin{array}{l}\text { Other } \\
\text { Unit }\end{array}$ & $\begin{array}{l}\text { UINSA } \\
\text { Member }\end{array}$ & Public \\
\hline $\begin{array}{l}\text { CRUD (Create, } \\
\text { Read, Update, } \\
\text { Delete) data at } \\
\text { sifasum.uinsby.a } \\
\text { c.id and Greensa } \\
\text { inn reservation }\end{array}$ & $\mathrm{R}, \mathrm{A}, \mathrm{C}$ & $\mathrm{R}, \mathrm{A}, \mathrm{C}$ & I & I \\
\hline $\begin{array}{l}\text { CRUD (Create, } \\
\text { Read, Update, } \\
\text { Delete) data at } \\
\text { IS PUSBIS }\end{array}$ & R,A,C,I & $\mathrm{C}$ & C,I & I \\
\hline $\begin{array}{l}\text { Check the } \\
\text { availability of } \\
\text { asset }\end{array}$ & A & A,C,I & $\mathrm{R}$ & $\mathrm{R}$ \\
\hline
\end{tabular}

\section{System Development}

After deciding to develop a system with agile, this study uses extreme programming, known as XP programming. In XP programming (Pressman, 2005), after designing and identifying system requirements, just immediately deploy or develop programs ranging from analysts, design, and implementation or system programming. If there is a revision or new menu, just repeat the same steps without having to have a sequence. The essence of this method is a fast program so without wasting too long.

\section{Analysis}

An analysis is part of planning. User requirements are carried out to determine the specifications of the product to be built, certainly adapted to business processes and interviews with people registered on the RACI chart. The analysis includes users, business processes, menus, data used, etc. After user requirements collection, then presented by flowchart to explain about the system flow.

\section{Database Design}

Database design is the design of a media store for IS. The database must be designed in such a way as it can affect system performance. This product using MySQL database with relational mode that have constructed via PHP my admin for the database dashboard system like presented at figure 3 .

\section{Interface Design}

Interface is IS display. In this case, what is meant by the interface is the design of an information system program that includes the homepage, login, dashboard, recapitulation, and logout. The following are the interface designs that have been designed for this product using web-based programming language, presented at figure 4: 


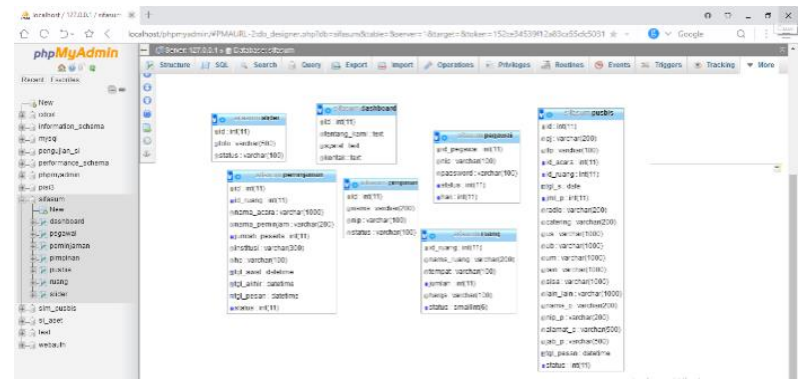

Figure 3. Database Design

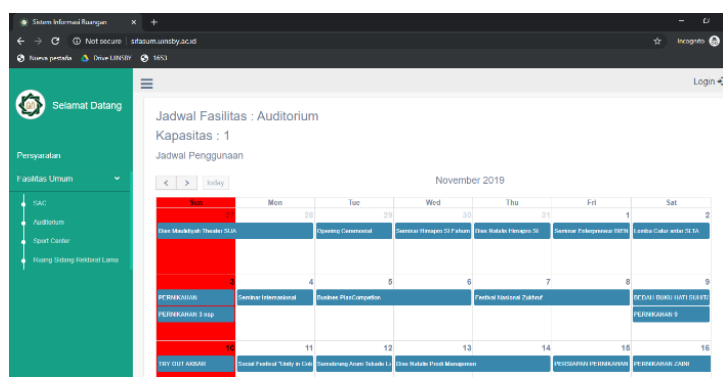

Figure 4. Interface Desig

\section{Coding}

Programming is the process of creating script lines that contain commands that be able to make the IS will run well. In this study, researchers used a framework or CodeIgniter framework. In CodeIgniter, an MVC model (model, view, controller) is applied. The source code is conducted based on the analysis and user requirements flowchart before.

\section{Implementation}

The implementation of the product in this research is to make them toward online with the domain of UINSA. The address of this product is sifasum.uinsby.ac.id. Then demonstrate all the systems or products that are built to the public are scattered starting from the UINSA community and the general public.

\section{Trial Test}

Tests have conducted in this study are a combination of methods that are often used in $R \& D$ research methods. In previous studies, there were testing methods that use small-scale and large-scale environments. Small-scale means testing in the scope of people with the same scientific field or expert. A large scale means that the test is carried out in public. There are also studies that use functionality and reliability.In this study, researchers tried to use a method of testing a combination of the two as in the following: 1. Small scale testing

which is carried out by an expert. Experts in this case are people who are struggling in the field of developing software or IS like programmer. 2. Testing functionality, in this case, is testing the system in the general public to test the extent of functional. What is highlighted in this test is the function and usefulness of the program. The point is to ensure that every function of the product can run properly. This session was conducted using questionnaires like explain before. This survey including the quality of service improvement using IS like publication, services, transaction, display and report variable.

The questionnaires have distributed by demonstrating the program on the study sample. Then the figures from the questionnaire are entered in a simple application made by a researcher specifically for this study as in the following figure: (STS, TS, N, S, SS are the values of questionare). After knowing the S / TS count then mapped based on the questionnaire questions as presented at figure 6 :

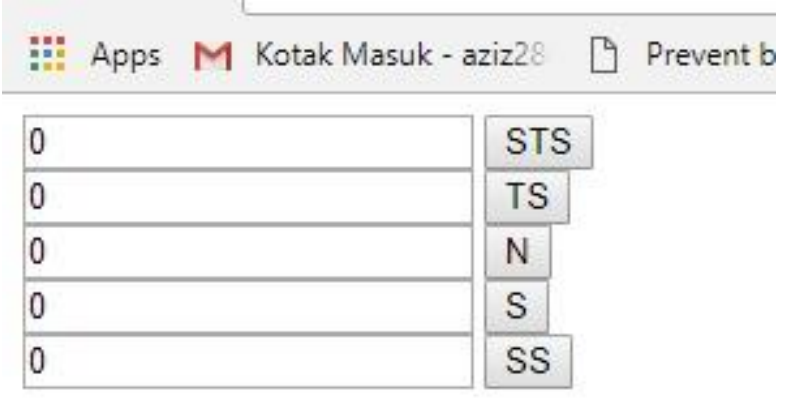

Figure 5. Functionalability Test Tools

\section{Revision}

Products that get complaints during testing are revised by researchers for the principle of the sustainability of this product later. This revised product will be submitted to the dissemination forum. The round of revision should be referred to as a research methodology above.

\section{Dissemination}

This dissemination was held on Thursday, October 5th 2017, at Greensa Inn Juanda. This dissemination is carried out by demonstrating the current products and opening discussions about the products being developed. Then the researchers distributed a dissemination questionnaire to the participants present and obtained data as follows on the figure 7. Figures 1-12 show the dissemination questionnaire questions that will be attached after this report. A or B shows the multiplechoice options in the questionnaire and the far left column shows the frequency. Some suggestions from the dissemination participants that we recap are as follows: The font is too small than it's hard for parents to see it, If opened on the cell phone is not yet responsive, Notfamiliar yet with the product link address. 


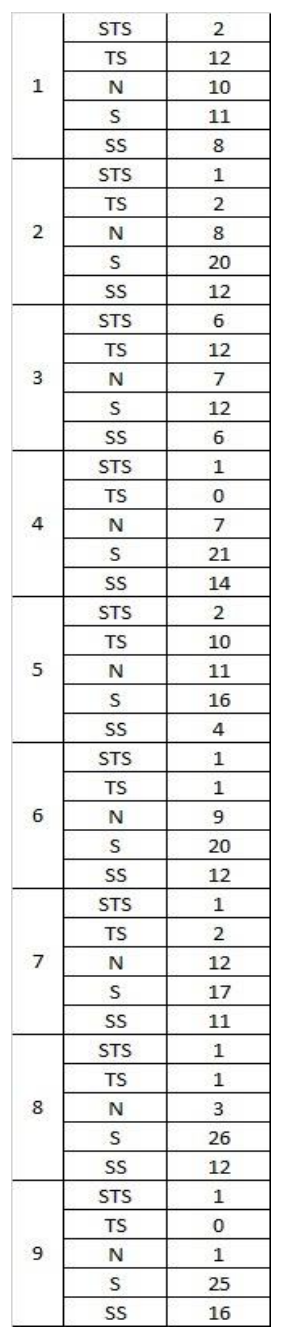

Figure 6. Functionalability Test Recapitulation

\begin{tabular}{c|c|c|}
\hline 1 & A & 25 \\
\hline & B & 4 \\
\hline 2 & A & 29 \\
\hline & B & 0 \\
\hline 3 & A & 19 \\
\hline & B & 10 \\
\hline 4 & A & 4 \\
\hline & B & 25 \\
\hline 5 & A & 10 \\
\hline & B & 19 \\
\hline 6 & A & 19 \\
\hline & B & 10 \\
\hline 7 & A & 17 \\
\hline & B & 12 \\
\hline 8 & A & 29 \\
\hline & B & 0 \\
\hline 9 & A & 29 \\
\hline & B & 0 \\
\hline 10 & A & 29 \\
\hline & B & 0 \\
\hline 11 & A & 23 \\
\hline & B & 6 \\
\hline 12 & A & 19 \\
\hline & B & 10 \\
\hline
\end{tabular}

Figure 7. Dissemination Recapitulation

\section{CONCLUSION AND SUGGESTION}

\section{Conclusion}

After this research is conducted based on the research methodology, here are the conclusion that can be presented as below:

1. The step of developing the development and implementation of the IS PUSBIS, greensa inn reservation and IS for public facilities that called sifasum.uinsby.ac.id at UINSA using agile XP programming. Here are the steps for developing these IS namely user requirements and system analysis for PUSBIS IS,Greensa inn reservation and IS for public facilities, subsequently the database and interface design then continued by coding session and ended by the implementation of IS.

2. The effectiveness of management IS in improving services at the business development center of UINSA Surabaya has increased based on the assessment of customers and users of UINSA services.

\section{Suggestion}

This suggestion is enforced because there are fields that have not been carried out on this research currently and may be continued by the next researchers. Below are the following suggestions that can be done:

1. The font is too small so for old people,it is very difficult to see it

2. Responsive display on cellphone

3. Product socialization or product launch on the main website uinsby.ac.id

4. Online transaction through the system

\section{ACKNOWLEDGEMENTS}

Thank you to Allah due to his grace and gift, we are able tocomplete this research along with my team. This research eternally dedicated to my campus UINSA hopefully you will grow always. Therefore, I would like to send warm and huge thank you to:

1. Department of Information System, Science and Technology Faculty, UINSA

2. Research Institute and Community Engagement (LP2M) UINSA

3. Our dearest support system and all parties engaged to help this research completely done.

\section{REFERENCES}

Akbar Ricky, d. (Oktober 2015). Implementasi Sistem Informasi Akademik Menggunakan Aplikasi Jibas pada SMA Negeri 9 Padang. TEKNOSI, Vol. 01, No. 01.

Arum Sari Kusuma Dewi, d. (2012). Implementasi E-Government System Dalam Upaya. JEAM, Vol XI No. 1/2012. ITGI. (2007). COBIT 4.1. 
Leod, M. (2004). Introduction to Information System. Prentice Hall, Inc.

Mayang, R. P. (2011). Perencanaan Strategis Sistem Informasi Pada Bintang Pelajar. UIN Syarif Hidayatulloh Jakarta.

Menteri Agama Republik Indonesia. (2015). Peraturan Menteri Agama Republik Indonesia Nomor 56 Tahun 2015 Tentang Statuta Universitas Islam Negeri Sunan Ampel Surabaya. Berita Negara Republik Indonesia Tahun 2016 Nomor 1729.

Millah, A. (2017). Analisa dan Perancangan Open Source Enterprise Resource Planning Untuk Meminimalisir Fraud Menggunakan Idempiere . Anca (p. 20). Banyuwangi: Jraba.

Millah,dkk. (2016). Sistem Informasi Fasilitas Umum UIN Sunan Ampel Surabaya. Surabaya: Sistem Informasi UINSA'14.

PEPPARD, J. W. (2002). Strategic Planning For Information System. ISBN 0-470-84147-8 Cranfield School of Management, Cranfield, Bedfordshire, UK.
Pusat Pengembangan Bisnis UIN Sunan Ampel Surabaya. (2015). Company Profile Pusat Pengembangan Bisnis UIN Sunan Ampel Surabaya. Surabaya: Pusat Pengembangan Bisnis UIN Sunan Ampel Surabaya.

Rameshb, G. K. (2015). Segmenting critical factors for enhancing the use of IT in. XVIII Annual International Conference of the Society of Operations Management (SOM-14). India.

Sugiyono. (2016). Research and Development. t.t: Alfabeta.

Susanto, T. (2017). Sukses Mengelola Layanan Teknologi Informasi \& Kiat Lulus Ujian Sertifikasi ITIL Foundation. Surabaya: Aisindo .

The Boston Consulting Group. (t.t). Putting Information Technology at the Core Of Bussiness. london: BCG.

Yuliar. (2001). Pemanfaatan Teknologi Informasi dan komunikasi pada industri kecil dan menengah di daerah". Puslitbag Aplikasi Informatika dan Informasi dan Komunikasi Publik. 